ACTA MYCOLOGICA

Vol. 49 (1): 69-78

2014
Dedicated to Professor Maria Ławrynowicz on the occasion of the 45th anniversary of her scientific activity

DOI: $10.5586 / \mathrm{am} .2014 .006$

\title{
Leccinum variicolor (Basidiomycota, Boletales) in Poland
}

\author{
MALGORZATA STASIŃSKA and ZOFIA SOTEK
}

\author{
Department of Botany and Nature Conservation, University of Szczecin \\ Felczaka 3c, PL-71-412 Szczecin; stasinsk@univ.szczecin.pl
}

Stasińska M., Sotek Z.: Leccinum variicolor (Basidiomycota, Boletales) in Poland. Acta Mycol. 49 (1): 69-78, 2014.

Leccinum variicolor Watling is widespread but it is a rare species in Poland and some other countries, and is either protected or red-listed. This paper describes the morphology and ecology of L. variicolor as well as its distribution in Poland.

Key words: macrofungi, threatened fungi, distribution, ecology

\section{INTRODUCTION}

The genus Leccinum Gray of the family Boletaceae Chevall. and the order Boletales E.-J. Gilbert is represented by ca. 75 species (Kirk et al. 2008). Fourteen of them are known from Poland (Wojewoda 2003; Łuszczyński 2008). Almost all species of this ectomycorrhizal genus are generally highly host-tree specific (Den Bakker et al. 2004). Leccinum variicolor is widespread, but not common in Europe, and occurs in the northern hemisphere, in the temperate, boreal, subalpine and arctic zones (e.g. Den Bakker, Noordeloos 2005; Knudsen, Taylor 2012; Noordeloos (online)). It is a rare species in Poland although it is known from various regions in the country, e.g. from the Lublin region (Flisińska 2004), the Wielkopolska region (Ślusarczyk 2007) and the Góry Świętokrzyskie Mts (Luszczyński 2007, 2008). Leccinum variicolor is included on the red list of macrofungi in Upper Silesia (Wojewoda 1999) and red list of Basidiomycetes in the Góry Świętokrzyskie Mts (Łuszczyński 2002, 2008). This paper describes the morphology and ecology of Leccinum variicolor as well as its distribution in Poland.

\section{MATERIAL AND METHODS}

The description of the basidiocarp morphology and habitats is based on original specimens and their localities, supplemented by information from the literature. 


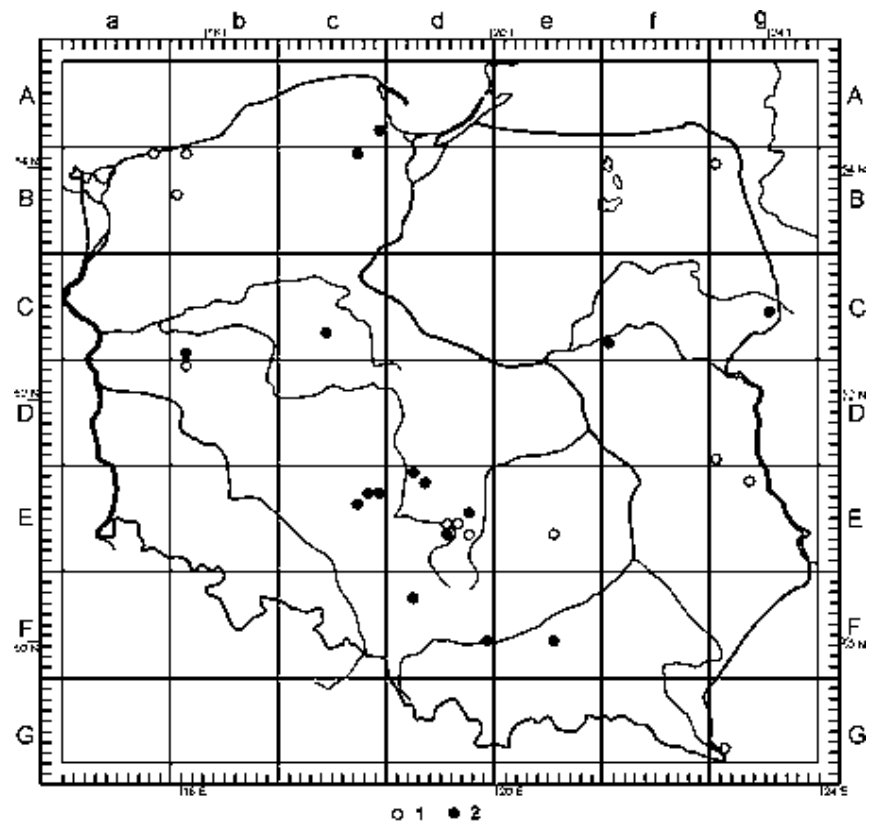

Fig. 1. Distribution of Leccinum variicolor in Poland, in ATPOL grid square system (Wojewoda 2000): 1 - data published, 2 - data unpublished.

Microscopic features were measured by standard light microscopy (LM). Basidia and spore measurements in the descriptions of the species are based on 30 measurements per specimen from 18 collections. Dimensions of the basidia and the spores are given as follows: (minimum value-) $1^{\text {st }}$ decile $-9^{\text {th }}$ decile (-maximum value). Spore length to width ratios are reported as Q. Micrographs were taken with a scanning electron microscope Zeiss EVO LS10 (SEM) in the Centre for Molecular Biology and Biotechnology, Environmental Testing Laboratory University of Szczecin (Poland). The cartogram map (Fig. 1) is based on our investigations and all available published data and unpublished (e.g. herbarium) records. The distribution was mapped using the grid square system following the "Atlas of the Geographical Distribution of Fungi in Poland" (Wojewoda 2000). Geographical regions are given after Kondracki (2002). The nomenclature of vascular plants follows Mirek et al. (2002) and that of plant communities follows Matuszkiewicz (2001). The specimens were collected by the authors in Pomerania during 1998-2011 and were deposited in the Herbarium of the Department of Botany and Nature Conservation, Szczecin University (SZUB), Poland.

\section{RESULTS}

Leccinum variicolor Watling, Notes R. bot. Gdn Edinb. 24: 268 (1969) - Boletaceae, Boletales, Agaricomycetidae, Agaricomycetes, Agaricomycotina, Basidiomycota, Fungi (Kirk et al. 2008). 
Syn.: Boletus variicolor (Watling) Hlaváček; Krombholziella variicolor (Watling) Šutara; Leccinum oxydabile (Singer) Singer ss. Kreisel, Pilát \& Dermek, Singer p.p.; Leccinum variicolor var. bertauxii Lannoy \& Estadès; for other synonymies see Index Fungorum.

Pileus 30-120 mm in diameter, convex to plano-convex, with entire margin, dark brown to blackish brown, greyish brown or mouse grey, usually with lighter ochraceous or yellowish grey spots, tomentous; tubes ventricose, 7-18 mm long, white when young, later grey or cream, vinaceous to brown when bruised; pores ca. 0.5 $\mathrm{mm}$ in diameter, white or cream, ochraceous when bruised; stipe 70-180 x 10-35 $\mathrm{mm}$, solid, cylindrical to clavate, white, with small grey to blackish brown squamules, often discolouring greenish blue at base; context white, gradually or quickly staining pink to coral red in pileus and apex of upper half of stipe, often intensely green blue in the lower half of stipe after 1-5 hours (Fig. 2); spores (10) 13.5-17.5 (20.0) x 5.06.5 (7.0) $\mu \mathrm{m}, \mathrm{Q}=2.4-3.1$, smooth, fusiform with or without a suprahilar depression (Fig. 3a, b); basidia 23.0-32.0 (34.2) x 8.5-11.0 (13.0) $\mu \mathrm{m}$, mostly with 4 sterigmata.

HABITAT AND DISTRIBUTION. Leccinum variicolor (mottled bolete) is a mycorrhizal species, closely associated with tree species of the genus Betula spp. (Den Bakker et al. 2004, 2007; Legon et al. 2009). It mainly grows on humid soil, peat or among Sphagnum spp., often in waterlogged sites. It occurs in mesic deciduous, coniferous and mixed forests, in open sites and in peatlands (e.g. Siller et al. 2005; Legon et al. 2009; Chinan 2011; Knudsen, Taylor 2012; Noordeloos (online)). In Poland, it has usually been noted in raised transitional bogs and their margins (e.g. Ślusarczyk 2007; Kujawa, Gierczyk 2011; Stasińska 2011). To date it has been recorded in associations such as Sphagno squarrosi-Alnetum (Halama, Romański 2010), Vaccinio uliginosi-Betuletum pubescentis and Vaccinio uliginosi-Pinetum (Flisińska 1987 (1988), 2004; Stasińska 2011) and communities such as Abies alba-Sphagnum girgensohnii (Łuszczyński 2007) and Betula pendula-Betula pubescens (Ślusarczyk 2007). It has recently been recorded in Erico-Sphagnetum medii, Myrico-salicetum auritae and the community Eriophorum vaginatum-Sphagnum fallax (Grzesiak 2010, unpublished).

Leccinum variicolor is widespread and its range is probably circumboreal (Knudsen, Taylor 2012; Noordeloos (online)). It is known in North America (Canada, USA), Asia (China, Japan) and Europe from, e.g., Austria, Estonia, France, Germany, Great Britain, Macedonia, Hungary, the Netherlands, Romania, Switzerland, and Scandinavian countries (Krieglsteiner 1991; Lannoy, Estades 1995; Den Bakker, Noordeloos 2005; Siller et al. 2005; Fu et al. 2006; Kalamees, Saar 2006; Den Bakker et al. 2007; Karadelew et al. 2007; Legon et al. 2009; Chinan 2011; Knudsen, Taylor 2012).

In Poland Leccinum variicolor is known from 30 localities. Published data are available for twelve sites (Flisińska 1987 (1988); Sałata 1988; Ślusarczyk 2007; Łuszczyński 2008; Gierczyk et al. 2009; Halama, Romański 2010; Kujawa, Gierczyk 2011, 2013; Stasińska 2011). The majority of localities are in southern Poland, chiefly in the Niziny Środkowopolskie plains and in the Wyżyna Małopolska upland. It has been recorded sporadically in other parts of Poland (Fig. 1).

Localities in Poland. Specimens indicated by asterisk (*) have not been examined by the authors.

Ac-89 - Pobrzeża Południowobałtyckie littoral regions: Gdańsk-Owczarnia (Trójmiejski Landscape Park); peat bog, among Sphagnum, 03.10.2009, leg. et det. M. Wantoch-Rekowski (unpublished, GREJ 2013)*. 

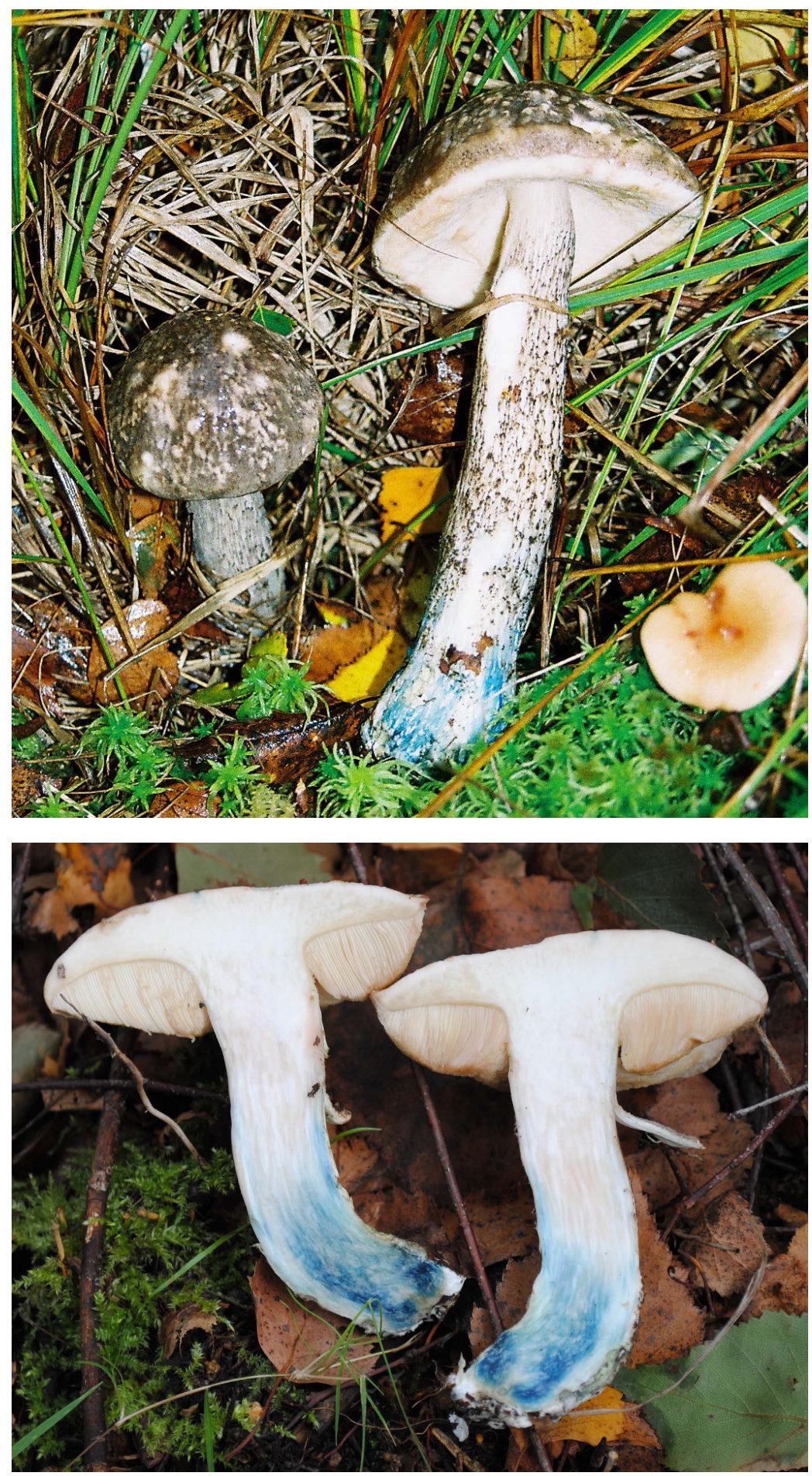

Fig. 2. Fruit-bodies of Leccinum variicolor recorded in Roby reserve (Photo by M. Stasińska). 

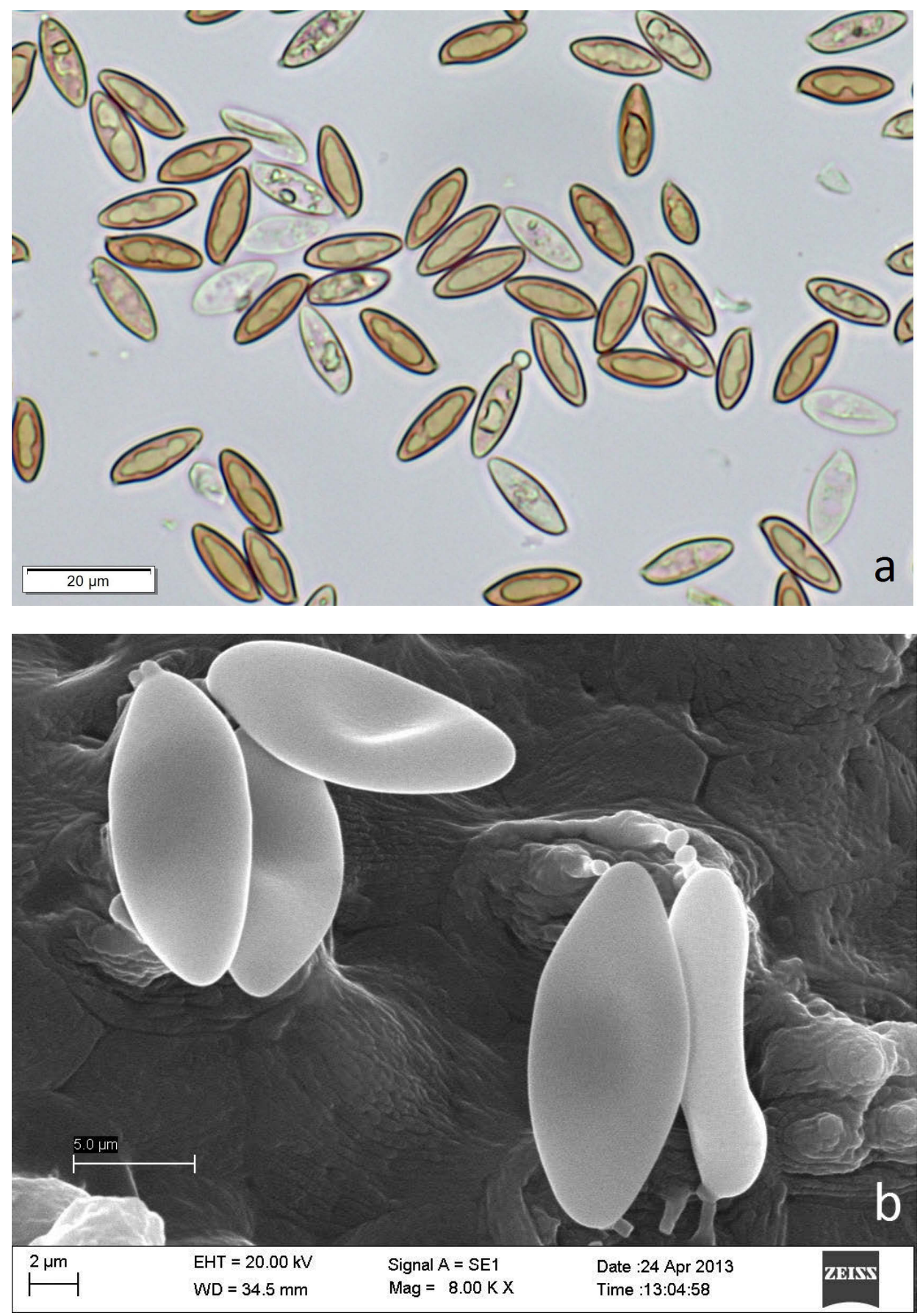

Fig. 3. Leccinum variicolor: a - spores seen by LM, b - spores seen by SEM. 
Ba-08 - Pobrzeża Południowobałtyckie littoral region: Roby reserve; raised bog, Vaccinio uliginosi-Betuletum pubescentis, on peat and among Sphagnum, under Betula, 26.09.2008, leg. et det. M. Stasińska, SZUB (Stasińska 2011); Myrico-Salicetum auritae, on peat under Betula, 19.09.2011, leg. Z. Sotek, det. M. Stasińska, SZUB (unpublished).

Bb-01 - Pobrzeża Południowobałtyckie littoral regions: Stramniczka reserve; raised bog, Vaccinio uliginosi-Betuletum pubescentis, on peat and among Sphagnum, under Betula, 27.09.2008, leg. et det. M. Stasińska, SZUB (Stasińska 2011); raised bog, Vaccinio uliginosi-Pinetum and Erico-Sphagnetum medii, among Sphagnum, 20.09.2011, leg. Z. Sotek et M. Stasińska, det. M. Stasińska, SZUB (unpublished).

Bb-40 - Pojezierza Południowobałtyckie lakelands: near Starea Dobrzyca reserve; raised bog, Vaccinio uliginosi-Betuletum pubescentis, among Sphagnum under Betula, 18.10.2006, leg. et det. M. Stasińska, SZUB (Stasińska 2011).

Bc-07 - Pojezierza Południowobałtyckie lakelands: Ostrzycki Las-Pierszczewko reserve; marginal part of peat bog, in mixed forest (e.g. Fagus, Alnus and Betula), 06.09.2009, leg. M. Wentoch-Rekowska, det. M. Wantoch-Rekowski (unpublished, GREJ 2013)*.

Bg-10 - Pojezierza Wschdniobałtyckie lakelands: Wigry National Park; Sphagno squarrosi-Alnetum, on soil (Halama, Romański 2010)*.

Cb-91 - Pojezierza Południowobałtyckie lakelands: Pszczew; peat bog, in mixed forest, among Sphagnum, 20.09.2009, leg. M. Wantoch-Rekowski, det. T. Ślusarczyk (unpublished, GREJ 2013)*.

Cc-74 - Pojezierza Południowobałtyckie lakelands: Gościeszynek (1.7 km SW), N of shore of Sykule Duże Lake; on soil, under Betula, 11.10.2012, leg. et det. B. Kudławiec (unpublished, GREJ 2013)*.

Cf-80 - Niziny Środkowopolskie lowlands: Lasy Łochowskie forests near Łazy; Vaccinio myrtilli-Pinetum, under Betula, 06.08.1985, leg. et det. Z. Domański; Herbarium of Z. Domański, KRAM-F 52147 (unpublished).

Cg-55 - Wysoczyzny Podlasko-Białoruskie high plains: Białowieski National Park; in forest, on soil, under Betula, 06.10.1989, leg. A. M. Słomczyńska and P. Słomczyński, det. W. Wojewoda, KRAM-F 30858 (unpublished).

Db-01 - Pojezierza Południowobałtyckie lakelands: Rybojady reserve; Betula pendula-Betula pubescens community, on soil and among Sphagnum, 10.07.2005, leg. et det. T. Ślusarczyk (Ślusarczyk 2007).

Dg-90 - Polesie region: Jezioro Czarne Sosnowickie reserve; Vaccinio uliginosiPinetum, among Calluna under Betula, 24.07.1984, leg. Z. Flisińska, LBLM (Flisińska 1987 (1988)).

Ec-28 - Niziny Środkowopolskie lowlands: Siedliska (1.3 km SW), Przedborów Forest District, forest section no. 798; in wet mixed forest (e.g. Alnus, Betula and Picea), on soil, 25.09.2012, leg. et det. P. Zawada (unpublished, GREJ 2013)**.

Ec-29 - Niziny Środkowopolskie lowlands: Łęki Duże (0.6 km NW), Przedborów Forest District, forest section no. 795; in wet mixed forest (e.g. Betula, Carpinus and Picea), on soil, 18.09.2012, leg. et det. P. Zawada (unpublished, GREJ 2013)*.

Ec-37 - Niziny Środkowopolskie lowlands: Leśniczówka Koziołek (0.9km NE), Przedborów Forest District, forest section no. 993; in wet mixed forest (e.g. Alnus, Betula, Picea and Pinus), on soil, 12.10.2012, leg. et det. P. Zawada (unpublished, GREJ 2013)*. 
Ed-02 - Niziny Środkowopolskie lowlands: Korzeń reserve (Złoczew Forest District, forest section no. 359); transitional bog, on slope between Eriophoro angustifolium-Sphagnetum recurvi and Leucobryo-Pinetum, under Betula, 30.09.2011, leg. et det. B. Grzesiak, LOD (unpublished).

Ed-13 - Niziny Środkowopolskie lowlands: Uroczysko Święte Ługi (Bełchatów Forest District); Eriophorum vaginatum-Sphagnum fallax community, under Betula, 19.09.2010, leg. et det. B. Grzesiak, LOD (unpublished).

Ed-47 - Niziny Środkowopolskie lowlands: Kotków $(1 \mathrm{~km} \mathrm{~W})$; in humid broadleaved forest (e.g. Alnus, Betula and Carpinus), on soil, 17.09.20011, leg. et det. J. Nowicki (unpublished, GREJ 2013)*.

Ed-55 - Wyżyna Małopolska upland: (1) Radziechowice I (2 km S); in broadleaved forest (e.g. Alnus and Betula), on soil; 02.09.2006, leg. et det. J. Nowicki (unpublished, GREJ 2013)*; in Scots pine and birch forest, on soil, 06.10.2011, leg. et det. J. Nowicki, ZBŚRiL PAN, 3/JN/20.12.11 (unpublished, GREJ 2013); (2) Szczepocice Prywatne ( $2 \mathrm{~km} \mathrm{E}$ ), in humid birch forest, on soil, 13.09.2009; leg. et det. J. Nowicki, ZBŚRiL PAN, 17/JN/15.10.09 (Kujawa, Gierczyk 2011); (3) Łęg (0.75 km SE); in wet Scots pine and birch forest, on soil, 24.09.2011, leg. et det. J. Nowicki (unpublished, GREJ 2013)*.

Ed-56 - Wyżyna Małopolska upland: Leśniczówka Strzałków $(0.3 \mathrm{~km} \mathrm{~S})$; in mixed forest (e.g. Abies, and Betula), on soil, 26.10.2008, 19.09.2010, leg. et det. J. Nowicki, ZBŚRiL PAN, 10/JN/10.12.10 (GREJ 2013*; Kujawa, Gierczyk 2013).

Ed-65 - Wyżyna Małopolska upland: Jamrozowizna $(1 \mathrm{~km} \mathrm{E})$; in mixed forest (e.g. Pinus and Betula), on soil, 10.09.2011, leg. et det. J. Nowicki, ZBŚRiLPAN, 1/ JN/20.12.11 (unpublished, GREJ 2013).

Ed-67 - Wyżyna Małopolska upland: Kotfin $(1.7 \mathrm{~km} \mathrm{E})$; on the marginal part of peat bog in Scots pine forest, under Betula, on soil, 04.10.2009; leg. et det. J. Nowicki, ZBŚRiLPAN, 16/JN/15.10.09 (Kujawa, Gierczyk 2011).

Ee-65 - Wyżyna Małopolska upland: Czostkowa Mt., Klonów, Abies alba-Sphagnum girgensohnii community, among Sphagnum under Betula; 15.09.1999, leg. et det. J. Łuszczyński, KTCB 1254 (Łuszczyński 2007, 2008).

Eg-13 - Polesie region: Bachus reserve near Chełm (Sałata 1988; Flisińska 2004)*.

Fd-22 - Wyżyna Śląsko-Krakowska upland: Świerklaniec (park); between forest and moist meadow, under Betula pendula, Tilia cordata and Quercus robur, 14.09.1979, leg. et det. M. Szczepka, KRAM-F 17997 (unpublished).

Fd-69 - Wyżyna Śląsko-Krakowska upland: Budzyń near Mydlniczka, ca. 12 km NE of Kraków; peat bog, 20.08.2006, leg. J. \& M. Piątek, det. M. Piątek, KRAM-F 54998 (unpublished).

Fe-65 - Północne Podkarpacie region: Łęki Dolne, ca. 18 km E of Tarnów, in humid birch forest, 13.08.1999, leg. Anonymous, det. M. Piątek, KRAM-F 39520 (unpublished).

Gg-61 - Beskidy Wschodnie Mts: Bieszczadzki National Park, Tarnawa reserve; raised bog, among Sphagnum under Betula, 18.08.2008, leg. et det. T. Ślusarczyk; 18/ TŚ/BdPN/180808 (Gierczyk et al. 2009). 


\section{DISCUSSION AND CONCLUSIONS}

In Europe, Leccinum variicolor is regarded as a rare species, more frequent only in Northern Europe (Knudsen, Taylor 2012; Noordeloos, online). It usually occurs in different forest communities, in tree stands where birch, which is its mycorrhizal partner, is either a dominant species or an admixture (Den Bakker et al. 2004, 2007; Legon et al. 2009). This would indicate that the species should be considerably more frequent. Sometimes considerable morphological similarity is observed between Leccinum variicolor and Leccinum scabrum, and these two species may not be distinguished in the field. They are distinguished by the flesh at the stem base which turns blue-green in $L$. variicolor but the colouration may be visible after a few hours. Both taxa also differ by habitat requirements. L. scabrum mainly grows in dry places (e.g. Wojewoda 2003) while L. variicolor occurs in moist sites, wetlands and peatlands (Chinan 2011; Stasińska 2011; Knudsen, Taylor 2012).

Although it is widespread, Leccinum variicolor is a rare and protected species in many European countries (e.g. Siller et al. 2005) or it is red-listed, e.g., in Romania (Tănase, Pob 2005; treated as vulnerable VU), in the Czech Republic (Holec, Beran 2006; treated as near threatened NT) and in Hungary (Siller, Vasas 1995; treated as endangered, vulnerable and rare - category 2). In Poland, the species is included on regional red lists of fungi only in Upper Silesia (category I - indeterminate, Wojewoda 1999) and the Góry Świętokrzyskie Mts (category R - rare, Łuszczyński 2002; category NT - near threatened, Łuszczyński 2008). It may be recommended to include the species on the national red list of macrofungi (Wojewoda, Ławrynowicz 2006) as nearly half of all its records in Poland to date are from peatlands and its margins (cf. the list of localities). According to Krieglsteiner (2000), wetland draining, occurring worldwide for many years, is a threat to $L$. variicolor.

The distribution of $L$. variicolor in Poland is not recognized well and the number of its sites may be greater than it is believed. Based on the available published and unpublished data and our observations, the species is probably rare and threatened in Poland.

Acknowledgements. The authors would like to thank the curators of all the herbaria for the loan of specimens. We are grateful to Dr. Barbara Grzesiak (University of Łódź) for making her unpublished material available for publication in the present paper. We would also like to express our gratitude to Dr. Bożena Białecka and Dr. Magdalena Bihun (Centre for Molecular Biology and Biotechnology, Environmental Testing Laboratory, University of Szczecin (Poland)) for taking SEM pictures. We are indebted to the anonymous reviewer for helpful suggestions on the manuscript.

\section{REFERENCES}

Chinan V. 2011. Macrofungi from „Grădiniţa“ peat bog (Eastern Carpatians, Romania). Biologie vegetală 57 (1): 35-40.

Den Bakker H.C., Noordeloos M.E. 2005. A revision of European species of Leccinum Gray and notes on extralimital species. Persoonia 18: 511-587.

Den Bakker H.C., Zuccarello G.C., Kuyper Th.W., Noordeloos M.E. 2004. Evolution and host specificity in the ectomycorrhizal genus Leccinum. New Phytologist 163: 201-215. 
Den Bakker H.C., Zuccarell, G.C., Kuyper Th.W., Noordeloos M.E. 2007. Phylogeographic patterns in Leccinum sect. Scabra and the status of the arctic-alpine species L. rotundifoliae. Mycological Research 3: 663-672.

Flisińska Z. 1987 (1988). Macromycetes zbiorowisk leśnych i torfowiskowych Pojezierza Łęczyńsko Włodawskiego. Acta Mycol. 23 (1): 19-92.

Flisińska Z. 2004. Grzyby Lubelszczyzny. I, II. Lubelskie Tow. Nauk., Merpol s.c., Lublin.

Fu S.-Z., Wang Q.-B., Yao Y.-J. 2006. An annotated checklist of Leccinum in China. Mycotaxon 96: 47-50.

Gierczyk B., Chachuła P., Karasiński D., Kujawa A., Kujawa K., Pachlewski T., Snowarski M., Szczepkowski A., Ślusarczyk T., Wójtowski M. 2009. Grzyby wielkoowocnikowe polskich Bieszczadów. I. Parki nar.: Rez. Przyr. 28 (3): 3-100.

GREJ 2013. Leccinum variicolor Watling. GREJ - Rejestr gatunków grzybów chronionych i zagrożonych w Polsce. http://www.grzyby.pl/gatunki/Leccinum_variicolor.htm

Halama M., Romański M. 2010. Grzyby makroskopijne (macromycetes). (In:) L. Krzysztofiak (ed.). Śluzowce Myxomycetes, grzyby Fungi i mszaki Bryophyta Wigierskiego Parku Narodowego. Przyroda Wigierskiego Parku Narodowego, seria naukowa. Stowarzyszenie „Człowiek i Przyroda”, Suwałki: 87-201.

Holec J., Beran M. (eds). 2006. Červený seznam hub (makromycetů) České republiky [Red list of fungi (macromycetes) of the Czech Republic]. Př́roda 24, Praha.

Index Fungorum. CABI Bioscience, CBS \& Landcare Research. http://www.indexfungorum.org/Names/ Names.asp

Kalamees K., Saar I. 2006. Mycobiota of the Naissaar Nature Park (Estonia). Folia Cryptog. Estonica. Fasc. 42: 25-41.

Karadelew M., Rusevska K., Spasikova S. 2007. The familly Boletaceae s.l. (excluding Boletus) in the Republic of Macedonia. Turk. J. Bot. 31: 539-550.

Kirk P.M., Cannon P.F., Minter D.W., Stalpers J.A. 2008. Ainsworth \& Bisby's Dictionary of the Fungi. $10^{\text {th }}$ Edition. CABI Europe - UK. Cromwell Press, Trowbridge.

Knudsen H., Taylor A. 2012. Leccinum Gray. (In:) H. Knudsen, J. Vesterholt (eds). Funga Nordica. Nordsvamp, Copenhagen: 223-227.

Kondracki J. 2002. Geografia regionalna Polski. PWN, Warszawa.

Krieglsteiner G.J. 1991. Verbreitungsatlas der Großpilze Deutschlands (West). 1. Ständerpilze. Teil A: Nichtblätterpilze. E. Ulmer GmbH \& Co., Stuttgard.

Krieglsteiner G.J. (Hrsg.) 2000. Die Großpilze Baden-Württembergs. Bd. 2. Verlag Eugene Ulmer, Stuttgart.

Kujawa A., Gierczyk B. 2011. Rejestr gatunków grzybów chronionych i zagrożonych w Polsce. Część V. Wykaz gatunków przyjętych do rejestru w roku 2009. Przegląd Przyr. 22 (4): 16-68.

Kujawa A., Gierczyk B. 2013. Rejestr gatunków grzybów chronionych i zagrożonych w Polsce. Część VI. Wykaz gatunków przyjętych do rejestru w roku 2010. Przegląd Przyr. 23 (4): 3-59.

Lannoy G., Estades A. 1995. Monographie des Leccinum D’Europe. Fédération Mycologique DauphonéSavoie, La Roche-sur-Foron.

Legon N.W., Henrici A., Roberts P.J., Spooner B.M., Watling R. 2009. Checklist of the British and Irish Basidiomycota, $4^{\text {th }}$ update of the printed version published 2005. http://www.basidiochecklist.info/

Łuszczyński J. 2002. Preliminary red list of Basidiomycetes in the Góry Świętokrzyskie Mts (Poland). Pol. Bot. J. 47 ( 2): 183-193.

Łuszczyński J. 2007. Diversity of Basidiomycetes in various ecosystems of the Góry Świętokrzyskie Mts. Monogr. Bot. 97: 1-118.

Łuszczyński J. 2008. Basidiomycetes of the Góry Świętokrzyskie Mts a checklist. Wyd. Uniwersytetu Humanistyczno-Przyrodniczego Jana Kochanowskiego, Kielce.

Matuszkiewicz W. 2001. Przewodnik do oznaczania zbiorowisk roślinnych Polski. Wyd. Naukowe PWN, Warszawa.

Mirek Z., Piękoś-Mirkowa H., Zając A., Zając M. (eds). 2002. Flowering Plants and Pteridophytes of Poland. A checklist. (In:) Z. Mirek (ed.). Biodiversity of Poland. 1. W. Szafer Institute of Botany, Polish Academy of Sciences, Kraków.

Noordeloos (online). The genus Leccinum in western and central Europe. http://www.entoloma.nl/htlm/ leccinum_eng.htlm

Sałata B. 1988. Ogólnopolskie Sympozjum Mikologiczne „Flora, ekologia i rozmieszczenie geograficzne grzybów”. Folia Soc. Sc. Lub. 30: 3-9. 
Siller I., Vasas G. 1995. Red list of macrofungi of Hungary (revised edition). Studia Bot. Hung. 26: 7-14.

Siller I., Vasas G. Pál-Fám F., Bratek Z., Zagyva I., Fodor L. 2005. Hungarian distribution of the legally protected macrofungi species. Studia Bot. Hung. 36: 131-163.

Stasińska M. 2011. Macrofungi of raised and transitional bogs of Pomerania. Monogr. Bot. 101: 1-142.

Ślusarczyk T. 2007. Grzyby wielkoowocnikowe rezerwatu torfowiskowego „Rybojady”. Przegląd Przyr. 18 (3-4): 71-90.

Tănase C., Pob A. 2005. Red list of Romanian macrofungi species. Bioplatform - Romanian National Platform for Biodiversity. Edit. Academiei Române, Bucureşti: 101-107.

Wojewoda W. 1999. Czerwona lista grzybów wielkoowocnikowych Górnego Śląska. Centr. Dziedz. Przyr. Górn. Śląska. Raporty i Opinie 4: 8-51.

Wojewoda W. (ed.). 2000. Atlas of the geographical distribution of fungi in Poland. 1. W. Szafer Institute of Botany, Polish Academy of Sciences, Kraków.

Wojewoda W. 2003. Checklist of Polish Larger Basidiomycetes. (In:) Z. Mirek (ed.). Biodiversity of Poland. 7. W. Szafer Institute of Botany, Polish Academy of Sciences, Kraków.

Wojewoda W., Ławrynowicz M. 2006. Red list of the macrofungi in Poland. (In:) Z. Mirek, K. Zarzycki, W. Wojewoda, Z. Szeląg (eds). Red list of plants and fungi in Poland. 3 rd. ed. W. Szafer Institute of Botany, Polish Academy of Sciences, Kraków: 53-70.

\section{Leccinum variicolor (Basidiomycota, Boletales) w Polsce}

\section{Streszczenie}

Leccinum variicolor Watling (koźlarz różnobarwny), jest gatunkiem szeroko rozprzestrzenionym, prawdopodobnie o zasięgu cyrkumborealnym. Najczęściej zajmuje wilgotne siedliska, rośnie w różnego typu lasach oraz w miejscach otwartych i na torfowiskach. W pracy zamieszczono szczegółowy opis i ilustracje najważniejszych cech makro- i mikromorfologicznych owocników koźlarza różnobarwnego. Przedstawiono również informacje na temat taksonomii, ekologii i rozmieszczenia na świecie, oraz aktualną mapę jego rozmieszczenia w Polsce. Autorzy podkreślają, że na obszarze Polski jest to gatunek rzadki i prawdopodobnie zagrożony oraz proponują ujęcie tego taksonu na czerwonej liście grzybów wielkoowocnikowych w Polsce. 